\author{
International Journal of Natural Sciences Research \\ 2021 Vol. 9, No. 1, pp. $26-38$. \\ $\operatorname{ISSN}(e): 2311-4746$ \\ $\operatorname{ISSN}(p): 2311-7435$ \\ DOI: 10.18488/journal.63.2021.91.26.38 \\ (C) 2021 Conscientia Beam. All Rights Reserved. \\ check for
updates
}

\title{
PROCESS SIMULATION OF OXY-FUEL COMBUSTION FOR A 120 MW COAL-FIRED POWER PLANT USING ASPEN PLUS
}
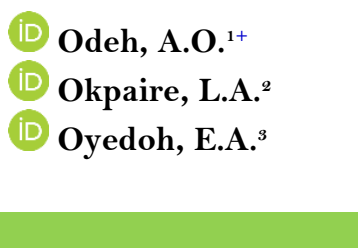

Article History

Received: 29 October 2021 Revised: 3 December 2021 Accepted: 17 December 2021 Published: 27 December 202

\section{Keywords}

Clean coal technology

Carbon capture

Coal sequestration

Coal combustion

Coal gasification.

\author{
${ }_{1,2, s}$ Department of Chemical Engineering, Faculty of Engineering, University \\ of Benin, Benin-City, Nigeria. \\ 'Email: andrew.odeh@uniben.edu Tel: +2348033188797 \\ Email:okpaire.lawso@gmail.com Tel:+2348118778186 \\ ${ }^{3}$ Email: egheoyedoh@uniben.edu Tel: +2348181892970
}

ABSTRACT

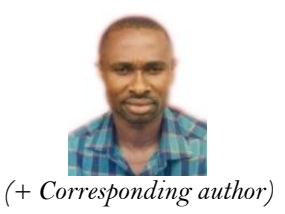

Oxy-fuel Combustion is a technology with the potential of drastically reducing the amount of $\mathrm{CO} 2$ emission, it relies on the use of oxygen and recycled $\mathrm{CO} 2$ instead of air as the oxidant. This helps to reduce the amount of the $\mathrm{CO} 2$ and $\mathrm{NOx}$ emissions. This study focuses on the components of flue gas produced and their amounts for oxy-fuel combustion in a coal-fired power plant (CFPP) and also the boiler efficiency using the direct (input-output) method. The combustion process of pulverized coal in a $120 \mathrm{MW}$ power plant is studied using Aspen Plus 11. The amount of each component in flue gas in coal-fired processes with air or $\mathrm{O}_{2} / \mathrm{CO} 2$ (using recycle of $20 \%, 40 \%, 60 \%$ and $80 \%$ of $\mathrm{CO} 2$ ) as oxidizer was obtained. From the process simulation, as the recycle \% of $\mathrm{CO} 2$ was increased, the flame temperature, $\mathrm{CO}$ and $\mathrm{NOx}$ emissions were reduced. The simulation results of air combustion were compared with that of oxy-fuel combustion with $80 \%$ recycle and it was seen that the flame temperature dropped from $18940 \mathrm{C}$ when air was used as oxidizer to $16790 \mathrm{C}$ for oxy-fuel combustion with $80 \%$ recycle. Also, there was a reduction in the amount of NOx produced, but the SOx levels were constant for both combustion processes. The Gross Calorific Value (GCV) of the coal was calculated from its Proximate Analysis using Dulong's formula and it was used to estimate the Boiler Efficiency using the Direct (Input-Output) method and a value of $83.6 \%$ was obtained.

Contribution/Originality: This study is one of the very few studies that has done a detailed evaluation of oxyfuel combustion of coal using Aspen plus in order to generate energy and also to combat emissions from coal usage through carbon capture and storage.

\section{INTRODUCTION}

Global energy consumption is rapidly growing coupled with a corresponding rise in the prices of oil has prompted a quest for alternate energy sources. In Nigeria for instance, this is a massive problem due to inconsistent electricity. This seemingly non-availability of power supply has affected negatively and severely lowered the output of numerous companies and household businesses. The results are significant losses and system breakdown which can wreak great havoc on a nation's economy. Coal burning is one of the common sources of electricity in many countries throughout the world and remain the major source of GDP to Nigeria's sister country, South Africa [1]. The combustion of coal makes provision for stable and sustainable fuel supplies. The combustion of coal is also a sustainable energy process as it utilizes existing infrastructure for mining, processing, and transportation, making it a very cost-effective procedure to many countries' portfolios. Carbon dioxide $\left(\mathrm{CO}_{2}\right)$ is commonly considered as the 
primary greenhouse gas. According to the International Energy Agency's (IEA) published statistics, global $\mathrm{CO}_{2}$ emissions summed up to 31.6 billion tons in 2011 , with coal burning accounting for approximately $40 \%$ of the total [2]. Due to these statistics, reducing $\mathrm{CO}_{2}$ emissions from coal-fired power plants (CFPP) is critical and have been a subject of debate and of great concern for over a decade now. In most first world countries, public awareness and laws had been enacted which have led to a number of policies in reducing greenhouse gas emissions. Most of the restrictions were influenced by international initiatives such as the Kyoto Protocol and the IPCC Intergovernmental Panel on Climate Change [3]. Previous studies on coal and coal products has revealed that $\mathrm{CO}_{2}$ produced from coal combustion and gasification processes can be trapped and stored in a variety of ways, including [4]:

Post combustion capture: $\mathrm{CO}_{2}$ produced by combustion in pulverized coal-fired power plants are captured via flue gas cleaning using chemical solvents, solid minerals, and other methods.

Pre-combustion capture: This involves trapping the $\mathrm{CO}_{2}$ before combustion: Integrated gasification combined cycle (IGCC) uses a shift reactor to convert $\mathrm{CO}$ to $\mathrm{CO}_{2}$.

Oxy-fuel Combustion: Combustion in oxygen rather than air using recovered flue gas is referred to as oxyfuel combustion. Chemical looping combustion: Oxygen is delivered using solid oxygen carriers and it reacts with fuel to produce a high-concentration $\mathrm{CO}_{2}$ stream in the flue gas, after which the oxygen carriers are regenerated to collect oxygen from air in a second reactor.

Oxy-fuel combustion is one of the most crucial $\mathrm{CO}_{2}$ capture methods for both new and current CFPPs. To produce $\mathrm{CO}_{2}$ rich stream appropriate for sequestration, coal is burned with a mixture of oxygen and recycled flue gas [5]. Oxy-fuel combustion is a very distinct pollution control measure and quite unique combustion technology [57]. At the same time, Oxides of nitrogen (NOx) emissions can be mitigated. Other gaseous emissions include water vapor, sulphur oxides (SOx), nitrogen oxides ( $\mathrm{NOx})$, carbon dioxide $\left(\mathrm{CO}_{2}\right)$, and usually some compounds identified as hazardous air pollutants (HAPs) including mercury [8]. Combustion of fuels containing sulphur always results in the emission of $\mathrm{SO}_{2}$ and $\mathrm{SO}_{3}$. The $\mathrm{SO}_{2}$ and $\mathrm{SO}_{3}$ reacts with the water vapour in the atmosphere to form sulphurous acid $\left(\mathrm{H}_{2} \mathrm{SO}_{3}\right)$ and sulfuric acid $\left(\mathrm{H}_{2} \mathrm{SO}_{4}\right)$ respectively. This dual by-product along with nitric acid $\left(\mathrm{HNO}_{3}\right)$ forms the components of acid rain. Acid rain is a major environmental issue because it can result in the damage of crops, forest degradation, reduced visibility, chemical breaking down of building stones and monuments, and promotes acidity of rivers and streams [7].

During the combustion process, NOx is one of the primary pollutants emitted into the environment. NOx is actually used to represent the emissions of nitric oxide $(\mathrm{NO})$, nitrogen dioxide $\left(\mathrm{NO}_{2}\right)$, and trace quantities of other nitrogen species. NOx is generated mainly from the combustion of fossil fuels at high temperatures and the presence of oxygen and nitrogen from both the air and fuel or only the fuel, in the case of oxy-fuel combustion [8]. Incomplete combustion of fuel represents wasted energy and causes an uprise in CO and Particulate Matter emissions. Although burning of liquid and gaseous fuels typically results in low CO emissions, control of unburned carbon in boiler ssystems that burn solid fuel (e.g., coal. Biomass etc.) is a crucial design and operating concern. Fuel properties, boiler and firing system characteristics, and unit operating conditions are some of the factors that affect Carbon burnout [8]. The fuel (either solid, liquid or gas) is burned using a mixture of oxygen (usually greater than 95 percent purity) and recycled flue gas in oxyfuel combustion. To ensure that there is the right gas to transmit the heat through the boiler, the recycled flue gas is used to stabilize flame temperature and cover up for the volume of the missing $\mathrm{N}_{2}$ (if air was used as oxidizer for the combustion). Boiler Efficiency is the energy absorbed by the boiler feed water during its conversion to superheated steam and is expressed as a percentage of the energy in the fuel. The boiler efficiency can be stated as either a net or a gross calorific value. Calorific values must be corrected to ambient temperature before being used in boiler calculations [9]. BS 845 is one of the standards for assessing boiler efficiency [10] however the two major approaches for determining boiler efficiency is by the "direct method" or the "indirect or loss method". In the Direct method (or Input-Output method), the difference between the energy in steam and the energy in boiler feed water, expressed as a percentage of the energy in fuel, is the boiler efficiency [9]. 


$$
\text { Boiler Efficiency }=\frac{\text { Energy in Steam-Energy in Boiler Feed Water }(B F W)}{\text { Energy in Fuel }} * 100 \%
$$

$$
\text { Boiler Efficiency }=\frac{\text { Mass of Steam } * \text { Enthalpy of Steam-Mass of BFW Enthalpyof BFW }}{\text { Energy in Fuel }} 100 \%
$$

The indirect method focuses on the Energy Lost; hence its name 'Loss Method' and it's represented by the equation below:

$$
\text { Boiler Efficiency }=\frac{\text { Energy in Fuel-Energy Losses }}{\text { Energy in Fuel }} * 100 \%
$$

Or

Boiler Efficiency = 100- L1-L2-L3-L4-L5

Where L1 to L5 are the various losses as a percentage of the total energy of the fuel

$\mathrm{L} 1=$ Latent heat loss in flue gas.

L2 $=$ Sensible Heat loss in the gas.

L3 = Loss due to unburn carbon.

L4 = Radiation loss.

L5 = Other losses such as incomplete combustion, heat in boiler ash, boiler blowdown, inward flow of cold air and outward flow of hot gases.

Process system simulation can be utilized to create a model of a coal fired power plant. Process system simulation is an established approach used in research for process engineering that relies on system engineering sciences that covers important fields such as chemical thermodynamics, chemical reaction kinetics, transfer phenomena, and gas-solid hydrodynamics with computer technology as the primary simulation instrument. Hysys, Chem CAD, Pro II, Aspen, and other advanced commercial software packages are available for process system simulation [11].

For sensitivity analysis, design optimization, and case studies, the Aspen Plus software package has been effectively employed to model several stable processes involving solids, electrolytes, coals, and biomass samples using the sequential modular method and the equation-oriented method [12]. From the standpoint of computable simulation, Aspen Plus can create a process simulation with reasonable reliability and adaptability [13]. Hence, In this study Aspen Plus is used to simulate oxy-fuel combustion of a 120MW coal fired power plant.

\section{METHODS AND MATERIALS}

\subsection{Simulation Method}

One of the simulation packages included in the Aspen Engineering Suite is Aspen Plus. AspenTech Int. Inc. designed and developed this software. The Aspen Plus simulator provides a sufficient and integrated solution for a chemical process, allowing users to assess the process' viability as well as carry out researches and investigate the effect of various operational parameters on the overall process being modelled. It is a powerful tool for simulation studies and aids in the analysis of process outcomes. The ASPEN Plus program is well-known for its ability to model a whole power plant on a large scale $[14,15]$. The Aspen Plus version 11 simulation tool was used to simulate the coal combustion process in this study and this was due to some important factors that were taken into consideration, such as: 
(1) Its ability to define non-traditional components in terms of ultimate and proximate analysis, as well as a large built-in physical database that may be employed in all simulation computations.

(2) Its ability to handle solids. Even if the solids effectively pass through the process as an inert component, the inclusion of solids in a process alters the heat and mass balances. Aspen Plus has a specific property model for solid particles that appropriately depicts them [14].

The flowsheet was set up in ASPEN Plus as "solids with metric units," and the simulation was given the MIXCINC stream class. Both conventional and non-traditional streams can be used in the simulation with the MIXCINC stream class. Non-conventional components are non-homogeneous substances with a variable composition that are not found in the Aspen Plus component database. The physical features of these components, such as coal, must be defined by traditional coal studies (ultimate and proximate, as well as sulphur analysis), whereas the traditional stream class was utilized to simulate all other streams in the simulation. The enthalpy and density of the substance must also be calculated using property procedures. The property methods HCOALGEN and DCOALIGHT were used to calculate the enthalpy and density of the coal in this study. Based on the ultimate, proximate, sulphur analyses, these property approaches use statistical correlations to calculate the specific heat, enthalpy, and density of the coal. The IDEAL base calculation approach was chosen for its simplicity; this allowed calculations to be done using the Ideal Gas Law.

\subsection{Process Description}

Figure 1 depicts the flow chart of oxy-fuel coal combustion. Wet coal is first placed in a drying block (RStoic), where it is dried by primary air (AIR1). This step lowers the moisture content from 10\% to $1 \%$. All nonconventional components are assumed to have a molecular weight of 1.0 by Aspen Plus. According to the reaction, 1 mol of coal reacts with $0.0555084 \mathrm{~mol}$ of water to produce $0.0555084 \mathrm{~mol}$ of water. By controlling the Fortran block, the moisture content of coal is reduced from $10 \%$ to $1 \%$. The chemical reaction for coal drying is Equation 6 . The coal is then placed in a FLASHING block (DRY-FLAS) to further evaporate the $\mathrm{H}_{2} \mathrm{O}$ from the system

$$
\mathrm{Coal} \text { (wet) } \longrightarrow 0.0555084 \mathrm{H}_{2} \mathrm{O}+\mathrm{Coal} \text { (dry) }
$$

The non-conventional solid dried coal feed (DRYCOAL) is first broken down into its constituents (C, H, O, N, S, and $\mathrm{ASH})$ and moisture $\left(\mathrm{H}_{2} \mathrm{O}\right)$. The RYIELD reactor, labelled DECOMP, performs the coal decomposition. It is a reactor model that generates products based on component yield specifications obtained from the ultimate analysis, and this determines the mass flowrate of each component in the RYIELD reactor block outlet stream (DECOMP) transformed to solid carbon graphite.

Gaseous $\mathrm{H}_{2}, \mathrm{O}_{2}, \mathrm{~N}_{2}, \mathrm{Cl}_{2}$ and $\mathrm{S}$ are formed from hydrogen, oxygen, nitrogen, chlorine, and sulphur. The moisture content is then transformed to liquid $\mathrm{H}_{2} \mathrm{O}$ at the end. The heat generated by coal decomposition (HEAT-DEC) is transferred to the Combustion Chamber (COMB-CHB). The Fortran block calculates the decomposition products $\mathrm{H}_{2} \mathrm{O}, \mathrm{H}_{2}, \mathrm{O}_{2}, \mathrm{~N}_{2}, \mathrm{Cl}_{2}, \mathrm{~S}, \mathrm{C}$, and Ash.

The combustion process is modelled using Gibb's reactor (COMB-CHB). The oxidant is a mix of $\mathrm{O}_{2}$ and $\mathrm{CO}_{2}$ from recovered flue gas. $\mathrm{H}_{2} \mathrm{O}, \mathrm{N}_{2}, \mathrm{O}_{2}, \mathrm{CO}, \mathrm{CO}_{2}, \mathrm{Cl}_{2}, \mathrm{SO}_{2}, \mathrm{SO}_{3}, \mathrm{NO}$ and $\mathrm{NO}_{2}$ are the primary by-products of coal combustion.

The combustion chamber products (COMB-PRD) were used to heat water (modelled using two heatersHEATERS 1 and 2) in order to produce steam at a pressure of 124.61 bar and a temperature of $537.78^{\circ} \mathrm{C}$, which were the inlet stream conditions for a 120MW thermal power plant with a correction factor of 1 [16]. The amount of feed water that will be fed into the unit is $6679 \mathrm{~kg} / \mathrm{h}$, according to the Water Design specification.

The ash and flue gas are separated in the solid's separation block (S-SEP) after passing through the heat block (Heater-1). The separation block (GAS-SEP) recycles flue gas in order to complete the process of pulverized coal combustion in an $\mathrm{O}_{2}$ and $\mathrm{CO}_{2}$ atmosphere. A Heater Block (Heater 3) lowers the temperature of the Exit Gas as it exits the Gas Separator (GAS-SEP). 


\subsection{Stream Data}

The simulation is carried out to meet the inlet stream conditions (temperature and pressure) of a 120MW CFPP unit by Geete and Khandwawala [16]. The coal sample used for the simulation in this study was bituminous coal. The results of the proximate, ultimate and sulphur analysis are as given in Table 1.

The mass flow rate of coal feed used for the study was $1000 \mathrm{~kg} / \mathrm{h}$ [13] while the mass of theoretical air per mass of bituminous coal basis is $9.07 \mathrm{~kg} / \mathrm{kg}$. The theoretical amount of oxygen consumed during the combustion was calculated based on this value. Assuming an excess air of $10 \%$. The mass of the dry coal that entered the combustion chamber (IN-COMB) was $909.1 \mathrm{~kg} / \mathrm{h}$, hence the amount of supplied air for combustion was $9070 \mathrm{~kg} / \mathrm{h}$ (mass flowrate of BRN-AIR in air combustion (Figure 2). The amount of oxygen supplied was $2104.25 \mathrm{~kg} / \mathrm{h}$ which is the flowrate of Oxygen in COMB-AIR for oxy-fuel combustion with $80 \%$ recycle. The recycled gas (GAS-REC) consists of $\mathrm{CO}_{2}$ ( $80 \%$ was recycled back to the Combustion Chamber) and $\mathrm{O}_{2}$ (all the oxygen was recycled back). From the calculated results of oxygen design specification, the mass flow rate of oxygen in stream AIR-2 is $1797.95 \mathrm{~kg} / \mathrm{h}$

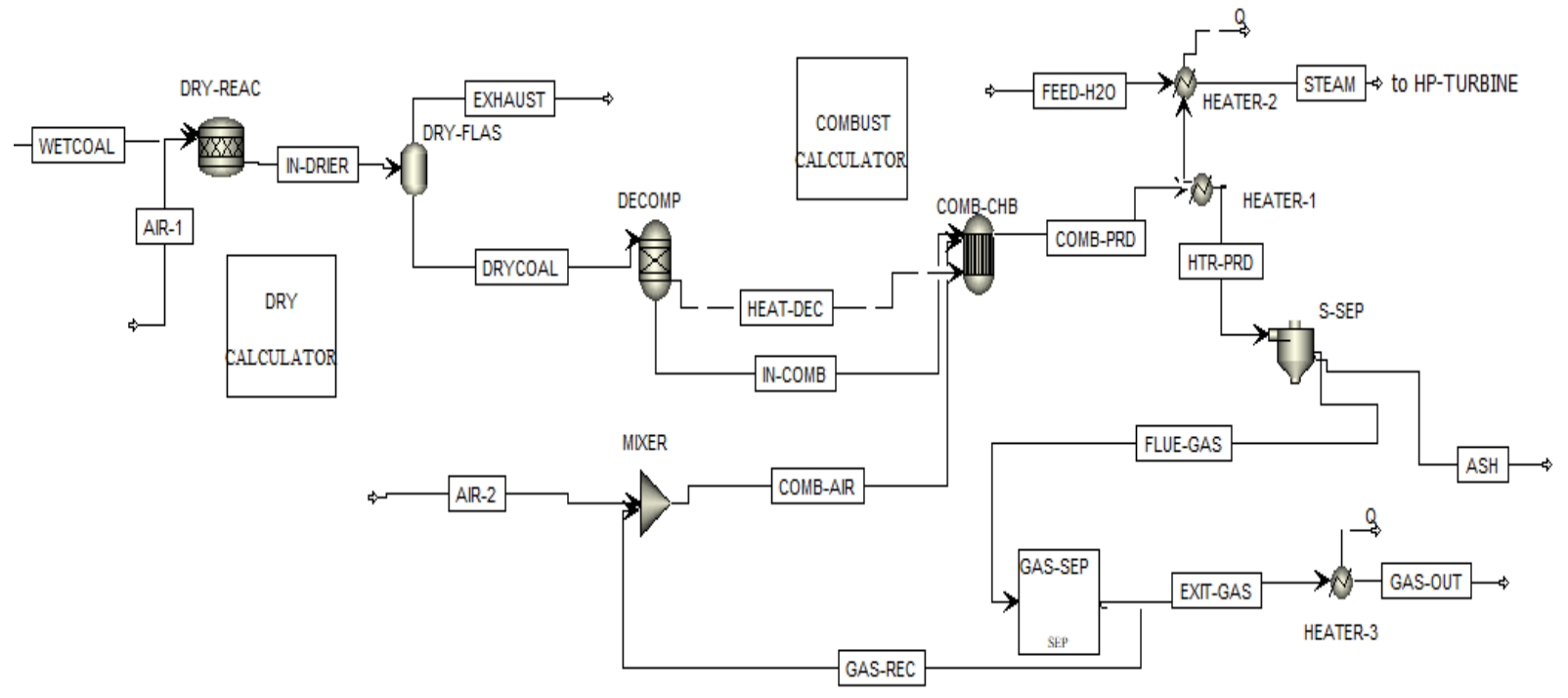

Figure-1. The flow sheet of Oxy-Fuel Coal Combustion.

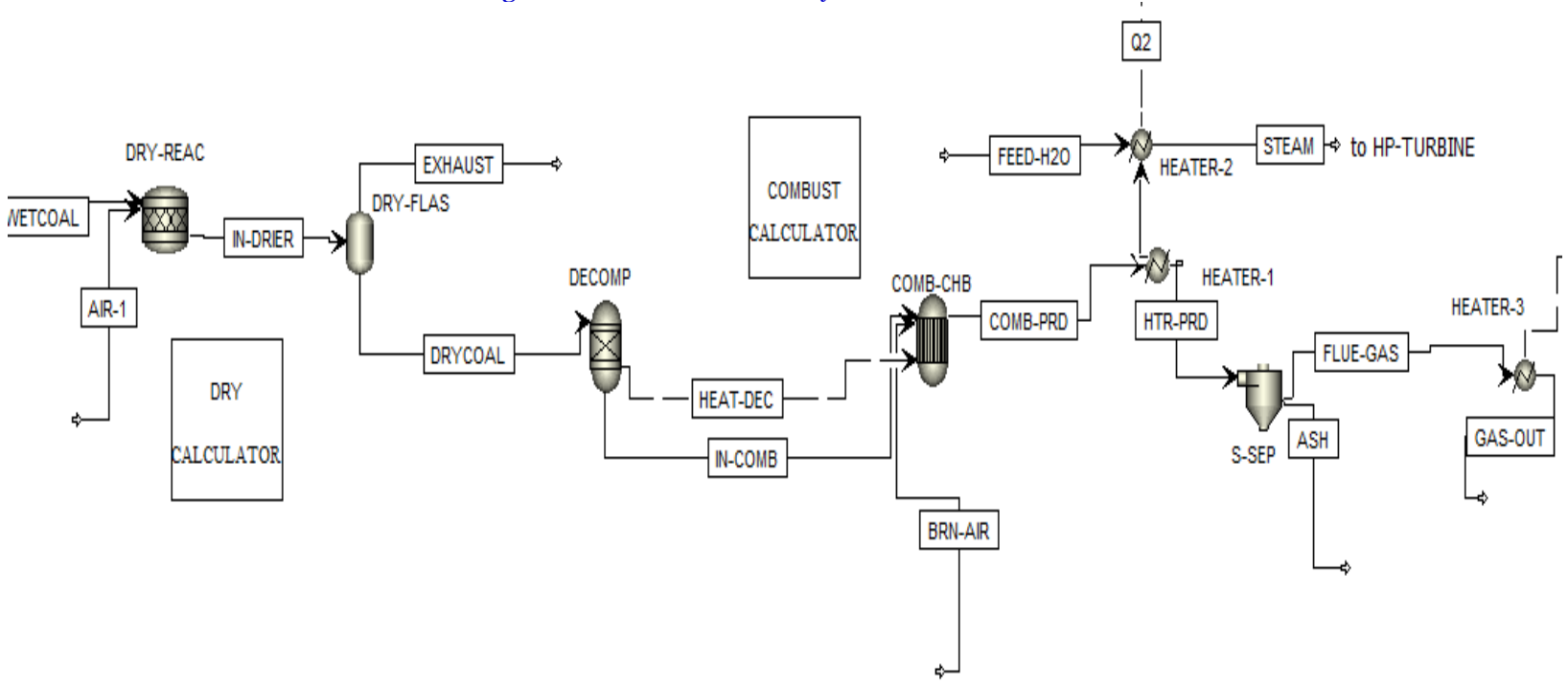

Figure-2. The flow sheet of Coal Combustion using Air. 
Table-1. Ultimate, Proximate and Sulphur Analysis of Bituminous coal.

\begin{tabular}{l|c}
\hline Ultimate Analysis (\%) & 10 \\
\hline Moisture & 9.2 \\
\hline Ash & 45.7 \\
\hline Volatile Matter & 45.1 \\
\hline Fixed Carbon & \\
\hline Proximate Analysis(\%) & 67.1 \\
\hline Carbon & 4.8 \\
\hline Hydrogen & 1.1 \\
\hline Nitrogen & 1.3 \\
\hline Sulphur & 0.1 \\
\hline Chlorine & 16.4 \\
\hline Oxygen & \\
\hline Sulphur Analysis(\%) & 0.6 \\
\hline Pyritic & 0.1 \\
\hline Sulfate & 0.6 \\
\hline Organic &
\end{tabular}

Table-2. Stream Data for air combustion and oxy-fuel combustion.

\begin{tabular}{l|c|c|c|c|c}
\hline & Wetcoal & AIR-1 & AIR-2 & FEED-H2O & BRN-AIR \\
\hline Temperature $\left({ }^{\circ} \mathrm{C}\right)$ & 25 & 300 & 25 & 25 & 25 \\
\hline Pressure $($ atm) & 1 & 1 & 1 & 1 & 1 \\
\hline Mass Flowrate $(\mathrm{kg} / \mathrm{h})$ & 1000 & 5000 & 1797.95 & 6679 & 9070 \\
\hline Component $($ mole fraction) & - & $21 \% \mathrm{O}_{2}+79 \% \mathrm{~N}_{2}$ & $100 \% \mathrm{O}_{2}$ & $100 \% \mathrm{H}_{2} \mathrm{O}$ & $21 \% \mathrm{O}_{2}+79 \% \mathrm{~N}_{2}$ \\
\hline
\end{tabular}

Table-3. Process models used in various parts of the Oxy-Fuel Combustion in ASPEN Plus.

\begin{tabular}{l|l|l}
\hline Name & Model & Function \\
\hline DRY-REAC & RStoic & Coal Drying \\
\hline DECOMP & RYIELD & Coal Decomposition \\
\hline COMB CHB & RGIBBS & Coal Combustion \\
\hline S-SEP & CYCLONE & Solid Separator \\
\hline HEATER-1 & HEATER & Cooling of Combustion products (COMB PRD) from COMB CHB \\
\hline HEATER-2 & HEATER & Heating of Feed H2O to produce STEAM \\
\hline HEATER-3 & HEATER & Cooling of EXIT-GAS \\
\hline GAS-SEP & SSPLIT & $\begin{array}{l}\text { Separating a portion of the FLUE-GAS consisting of mainly } \mathrm{CO}^{2} \text { and } \\
\mathrm{O}_{2} \text { for recycle }\end{array}$ \\
\hline
\end{tabular}

Table-4. Simulation Results of the Oxy-Fuel Combustion with a recycle of $80 \% \mathrm{CO}_{2}$ in $\mathrm{ASPEN}$ Plus.

\begin{tabular}{|c|c|c|c|c|c|c|c|c|c|}
\hline & AIR-2 & $\begin{array}{c}\text { COMB- } \\
\text { AIR }\end{array}$ & $\begin{array}{c}\text { COMB- } \\
\text { PRD }\end{array}$ & $\begin{array}{c}\text { EXIT- } \\
\text { GAS }\end{array}$ & $\begin{array}{c}\text { FLUE- } \\
\text { GAS }\end{array}$ & $\begin{array}{l}\text { GAS- } \\
\text { OUT }\end{array}$ & $\begin{array}{l}\text { GAS- } \\
\text { REC }\end{array}$ & $\begin{array}{l}\text { HTR- } \\
\text { PRD }\end{array}$ & STEAM \\
\hline $\operatorname{Temp}\left({ }^{\circ} \mathrm{C}\right)$ & 25 & 104.252 & 1679 & 120 & 120 & 30 & 120 & 120 & 537.78 \\
\hline Press(atm) & 1.00 & 1.00 & 1.00 & 1.00 & 1.00 & 1.00 & 1.00 & 1.00 & 124.61 \\
\hline Component & \multicolumn{9}{|c|}{ Mass Flowrate(kg/h) } \\
\hline $\mathrm{H}_{2} \mathrm{O}$ & 0.00 & 0.00 & 395.16 & 395.16 & 395.16 & 395.16 & 0.00 & 395.16 & 6679 \\
\hline $\mathrm{N}_{2}$ & 0.00 & 0.00 & 9.46 & 9.46 & 9.46 & 9.46 & 0.00 & 9.46 & 0.00 \\
\hline $\mathrm{O}_{2}$ & 1797.95 & 2104.25 & 306.30 & 0.00 & 306.30 & 0.00 & 306.30 & 306.30 & 0.00 \\
\hline $\mathrm{C}$ & 0.00 & 0.00 & 0.00 & 0.00 & 0.00 & 0.00 & 0.00 & 0.00 & 0.00 \\
\hline $\mathrm{H}_{2}$ & 0.00 & 0.00 & 0.00 & 0.00 & 0.00 & 0.00 & 0.00 & 0.00 & 0.00 \\
\hline $\mathrm{S}$ & 0.00 & 0.00 & 0.00 & 0.00 & 0.00 & 0.00 & 0.00 & 0.00 & 0.00 \\
\hline $\mathrm{Cl}_{2}$ & 0.00 & 0.00 & 0.90 & 0.90 & 0.90 & 0.90 & 0.00 & 0.90 & 0.00 \\
\hline $\mathrm{SO}_{2}$ & 0.00 & 0.00 & 23.35 & 23.35 & 23.35 & 23.35 & 0.00 & 23.35 & 0.00 \\
\hline $\mathrm{SO}_{3}$ & 0.00 & 0.00 & 0.035 & 0.035 & 0.035 & 0.035 & $\mathrm{O}$ & 0.035 & $\mathrm{O}$ \\
\hline $\mathrm{CO}_{2}$ & 0.00 & 8649.60 & 10811.9 & 2162.37 & 10811.9 & 2162.37 & 8649.60 & 10811.9 & 0.00 \\
\hline $\mathrm{CO}$ & 0.00 & 0.00 & 32.14 & 32.14 & 32.14 & 32.14 & 0.00 & 32.14 & 0.00 \\
\hline $\mathrm{NO}$ & 0.00 & 0.00 & 0.94 & 0.94 & 0.94 & 0.94 & 0.00 & 0.94 & 0.00 \\
\hline $\mathrm{NO}_{2}$ & 0.00 & 0.00 & 0.001 & 0.001 & 0.001 & 0.001 & 0.00 & 0.001 & 0.00 \\
\hline $\begin{array}{l}\text { Total Mass } \\
\text { Flow }(\mathrm{kg} / \mathrm{hr})\end{array}$ & 1797.95 & 10753.85 & 11579.29 & 2624.26 & 11579.29 & 2624.26 & 8955.90 & 11579.29 & 6679 \\
\hline
\end{tabular}


Table-5. Composition of Outlet flue gas under Air combustion and Oxy-fuel combustion with different Recycle percentages.

\begin{tabular}{|c|c|c|c|c|c|}
\hline & Air & $\begin{array}{c}20 \% \mathrm{CO}_{2} \\
\text { Recycle }\end{array}$ & $\begin{array}{c}40 \% \mathrm{CO}_{2} \\
\text { Recycle }\end{array}$ & $\begin{array}{c}60 \% \mathrm{CO}_{2} \\
\text { Recycle }\end{array}$ & $\begin{array}{c}80 \% \mathrm{CO}_{2} \\
\text { Recycle }\end{array}$ \\
\hline Flame Temperature & $1894^{\circ} \mathrm{C}$ & $3075^{\circ} \mathrm{C}$ & $2923^{\circ} \mathrm{C}$ & $2630^{\circ} \mathrm{C}$ & $1679^{\circ} \mathrm{C}$ \\
\hline $\mathrm{N}_{2}$ & 6946.883 & 4.429034 & 5.023538 & 6.307769 & 9.459961 \\
\hline $\mathrm{SO}_{2}$ & 23.36135 & 23.36812 & 23.36729 & 23.36548 & 23.3478 \\
\hline $\mathrm{CO}$ & 38.77668 & 1000.96 & 962.3332 & 802.3997 & 32.12072 \\
\hline $\mathrm{NO}$ & 43.81134 & 11.71529 & 10.44194 & 7.691676 & 0.942013 \\
\hline $\mathrm{NO}_{2}$ & 0.030096 & 0.00762 & 0.007246 & 0.005875 & 0.001023 \\
\hline $\mathrm{SO}_{3}$ & 0.017657 & 0.009203 & 0.010242 & 0.0125 & 0.03459 \\
\hline $\mathrm{Cl}_{2}$ & 0.9000 & 0.9000 & 0.9000 & 0.9000 & 0.9000 \\
\hline
\end{tabular}

\section{RESULTS AND DISCUSSION}

The simulation results are presented in Table 4. The major component of the stream FLUE-GAS was $\mathrm{CO}_{2}$ with the highest mass flowrate of $10811.90 \mathrm{~kg} / \mathrm{h}$ followed by $\mathrm{H}_{2} \mathrm{O}$ with $395.16 \mathrm{~kg} / \mathrm{h}$ then $\mathrm{O}_{2}$ with $306.30 \mathrm{~kg} / \mathrm{h}$. Other components in the FLUE-GAS are low in values.

\subsection{Comparison of Different Recycle Ratios in Oxy-Fuel Combustion}

The combustion of pulverized coal under atmospheric condition is shown in Figure 2. The major component of the combustion products of coal using air as the oxidant is $\mathrm{N}_{2}$.

Oxy-fuel combustion involved combustion in the presence of $\mathrm{O}_{2} / \mathrm{CO}_{2}$. The study was carried out with different recycle percentages of $\mathrm{CO}_{2}$ back to the combustion chamber $(20 \%, 40 \%, 60 \%$ and $80 \%)$.

The flame temperature for the oxy-fuel combustion with recycle percentages of $20 \%, 40 \%, 60 \%$ and $80 \%$ are given as $3075^{\circ} \mathrm{C}, 2923{ }^{\circ} \mathrm{C}, 2630{ }^{\circ} \mathrm{C}$ and $1679{ }^{\circ} \mathrm{C}$ respectively. Firing coal with pure oxygen will result in a tremendously high flame temperature which is very dangerous, so the recycled $\mathrm{CO}_{2}$ acts as a dilutant (the same function of $\mathrm{N}_{2}$ in the case of air combustion) and helps to reduce the flame temperature. The $\mathrm{CO}_{2}$ absorbs some of the heat produced during the combustion process such that the higher the amount of $\mathrm{CO}_{2}$ that is present during the combustion, the lesser the flame temperature. The implication of this act is that there is reduction in the concentration of $\mathrm{CO}_{2}$ present in the gaseous mixture of $\mathrm{O}_{2} / \mathrm{CO}_{2}$ sent to the combustion chamber. This invariably increases the $\mathrm{O}_{2}$ concentration and thus causes an increase in the flame temperature (since less heat is absorbed due to reduced $\mathrm{CO}_{2}$ ).

During the combustion process, $\mathrm{CO}$ and NOx are some of the major pollutants that are produced. NOx is one of the primary pollutants emitted into the atmosphere. NOx reacts with atmospheric precipitation to form acid rain, while CO reacts with the hemoglobin in the blood, thereby reducing the amount of oxygen transported in the body. From the results, the mass flowrates of NOx and CO was lowest in oxy-fuel combustion with recycle of $80 \%$, the mass flowrate of NOx was very low $(0.943 \mathrm{~kg} / \mathrm{h})$ when compared to oxy-fuel combustion with recycle of $20 \% \mathrm{CO}_{2}$ $(11.722 \mathrm{~kg} / \mathrm{h})$. The results shows that the higher the amount of $\mathrm{CO}_{2}$ recycled, the lower the NOx present in the flue gas. This is due to the fact that some of the recycled $\mathrm{CO}_{2}$ is reduced to $\mathrm{CO}$ by red hot coal which then reduces the $\mathrm{NOx}$ to $\mathrm{N}_{2}$

As can be seen in Table 5, the mass flowrates of carbon monoxide in the oxy-fuel combustion with recycle percentages of $20 \%, 40 \%, 60 \%$ and $80 \%$ are $1000.96 \mathrm{~kg} / \mathrm{h}, 962.332 \mathrm{~kg} / \mathrm{h}, 802.4 \mathrm{~kg} / \mathrm{h}$ and $32.12 \mathrm{~kg} / \mathrm{h}$ respectively. This again shows that the higher the amount of $\mathrm{CO}_{2}$ recycled back into the $\mathrm{O}_{2} / \mathrm{CO}_{2}$ mixture, the lower the amount of $\mathrm{CO}$ that is present in the flue gas, the difference in the amount of $\mathrm{CO}$ emitted between recycles of $20 \%$ and $80 \%$ is actually quite significant. This can be attributed to the fact that some of the $\mathrm{CO}_{2}$ that is recycled into the combustion chamber is reduced to $\mathrm{CO}$ by hot coal. $\mathrm{CO}$ is a good reducing agent and reduces the NOx that are formed after the 
combustion process to $\mathrm{N}_{2}$ while the $\mathrm{CO}$ itself is oxidized back to $\mathrm{CO}_{2}$ hence the concentrations of $\mathrm{NOx}$ and $\mathrm{CO}$ decreases while that of $\mathrm{CO}_{2}$ increases

$$
\begin{aligned}
& \mathrm{CO}_{2}+\mathrm{C} \longrightarrow 2 \mathrm{CO} \\
& 2 \mathrm{NO}+2 \mathrm{CO} \Longrightarrow 2 \mathrm{CO}_{2}+\mathrm{N}_{2} \\
& \mathrm{NO}_{2}+\mathrm{CO} \rightleftharpoons \mathrm{N}_{2}+\mathrm{CO}_{2}
\end{aligned}
$$

\subsection{Oxy-Fuel Combustion vs Air Combustion}

The flame temperature of the air combustion and oxy-fuel combustion with $80 \%$ recycled $\mathrm{CO}_{2}$ was compared and the result shows that the flame temperature using air was higher $\left(1894^{\circ} \mathrm{C}\right)$ than that of oxy-fuel combustion with $80 \%$ recycled $\mathrm{CO}_{2}\left(1679^{\circ} \mathrm{C}\right)$. This can be traced to the heat capacities of both $\mathrm{N}_{2}$ and $\mathrm{CO}_{2}$. $\mathrm{CO}_{2}$ has a higher heat capacity meaning it takes more heat to increase its temperature, hence if both $\mathrm{N}_{2}$ and $\mathrm{CO}_{2}$ were subjected to the same amount of heat, $\mathrm{N}_{2}$ will have a higher temperature. From the results in Table 5, it can be seen that the flowrate of NOx was highest in the air combustion $(43.841 \mathrm{~kg} / \mathrm{h})$ compared to oxy-fuel combustion, in fact the decrease of NOx was very tremendous in oxy-fuel combustion with recycle of $80 \%(0.943 \mathrm{~kg} / \mathrm{h})$ which means that the formation of NOx is restrained effectively by oxyfuel combustion. In atmospheric (air) combustion, the $\mathrm{N}_{2}$ is from the coal and also from the air but in oxy-fuel combustion, the $\mathrm{N}_{2}$ is only present in the coal and the NOx formed during oxyfuel combustion is reduced to molecular nitrogen, $\mathbf{N}_{2}$. This results corroborates the report by Odeh [17]; Odeh [18] that worked on pyrolysis of six demineralized coals of different ranks

The mass flowrate of $\mathrm{SOx}$ (both $\mathrm{SO}_{2}$ and $\mathrm{SO}_{3}$ ) was quite constant for the two types of combustion process $23.376 \mathrm{~kg} / \mathrm{hr}$, for air combustion and $23.382 \mathrm{~kg} / \mathrm{hr}$ for oxyfuel combustion with $80 \%$ recycle.

\subsection{Sensitivity Analysis}

Figures $3-5$ presents effects of temperature on the formation of the oxides of carbon, nitrogen and Sulphur. The increase of temperature causes the amounts of $\mathrm{NO}, \mathrm{SO}_{2}$ and $\mathrm{CO}$ to increase, whereas the amounts of $\mathrm{N}_{2}, \mathrm{SO}_{3}$ and $\mathrm{CO}_{2}$ decreases. The mass flow rate of $\mathrm{NO}$ is affected by temperature, increasing from $0.0477 \mathrm{~kg} / \mathrm{h}$ to $2.3706 \mathrm{~kg} / \mathrm{h}$ in the temperature range of $1000{ }^{\circ} \mathrm{C}$ to $2000{ }^{\circ} \mathrm{C}$, which corresponds to a decrease in the mass flow rate of $\mathrm{N}_{2}$ from $9.878 \mathrm{~kg} / \mathrm{hr}$. to $8.793 \mathrm{~kg} / \mathrm{h}$. This shows that the formation of NOx is favored at high temperatures

The mass flow rate of $\mathrm{SO}_{2}$ increases from $22.783 \mathrm{~kg} / \mathrm{hr}$ to $23.360 \mathrm{~kg} / \mathrm{hr}$ when the temperature is increased from $1000{ }^{\circ} \mathrm{C}$ to $2000{ }^{\circ} \mathrm{C}$ also the amount of $\mathrm{CO}_{2}$ decreases from $11063.8 \mathrm{~kg} / \mathrm{h}$ to $9145.9 \mathrm{~kg} / \mathrm{h}$ and the $\mathrm{CO}$ increases from $0.0034 \mathrm{~kg} / \mathrm{h}$ to $244.131 \mathrm{~kg} / \mathrm{h}$. When the temperature is between $1500{ }^{\circ} \mathrm{C}$ to $1750{ }^{\circ} \mathrm{C}$, the mass flow rate of $\mathrm{CO}$ increased a bit faster and at temperatures above $1750{ }^{\circ} \mathrm{C}$, the increase was very rapid. The mass flow rate $\mathrm{CO}_{2}$ decreased spontaneously because $\mathrm{CO}_{2}$ is reduced by coal to generate $\mathrm{CO}$ at high temperatures.

The influence of the excess oxygen in the range of $10 \%-30 \%$ on the flue gas composition is shown in Figures 6 to Figure 8. These figures indicates that the generation of $\mathrm{NOx}, \mathrm{SO}_{3}$ and $\mathrm{CO}_{2}$ is enhanced by increasing the excess oxygen ratio and the amounts were increased by $0.298,0.0221$ and $128.7 \mathrm{~kg} / \mathrm{h}$ respectively when the excess oxygen is increased from $10 \%$ to $30 \%$. The generation of $\mathrm{N}_{2}, \mathrm{SO}_{2}$ and $\mathrm{CO}$ was suppressed and the amounts were decreased by $0.14,0.02$ and $16.52 \mathrm{~kg} / \mathrm{h}$ respectively. This can be attributed to the fact that at high oxygen concentration (excess oxygen), $\mathrm{N}_{2}, \mathrm{CO}, \mathrm{SO}_{2}$ is oxidized to their higher oxides i.e., $\mathrm{NO}, \mathrm{CO}_{2}$ and $\mathrm{SO}_{3}$ respectively.

\subsection{Steam Output and Thermal Efficiency}

The main aim of the study was to stimulate a 120MW oxyfuel combustion (with $80 \%$ recycle) for a coal fired power plant. The inlet steam conditions were 124.61 bar and $537.78^{\circ} \mathrm{C}$ [16]. The heat that was produced from the combustion process was used to raise the temperature of feed water at $25^{\circ} \mathrm{C}$ to pressurized steam. From Design specification, it was seen that $6697 \mathrm{~kg} / \mathrm{h}$ of steam at $124.61 \mathrm{bar}$ and $537.78^{\circ} \mathrm{C}$ could be produced (provided no energy was wasted). 

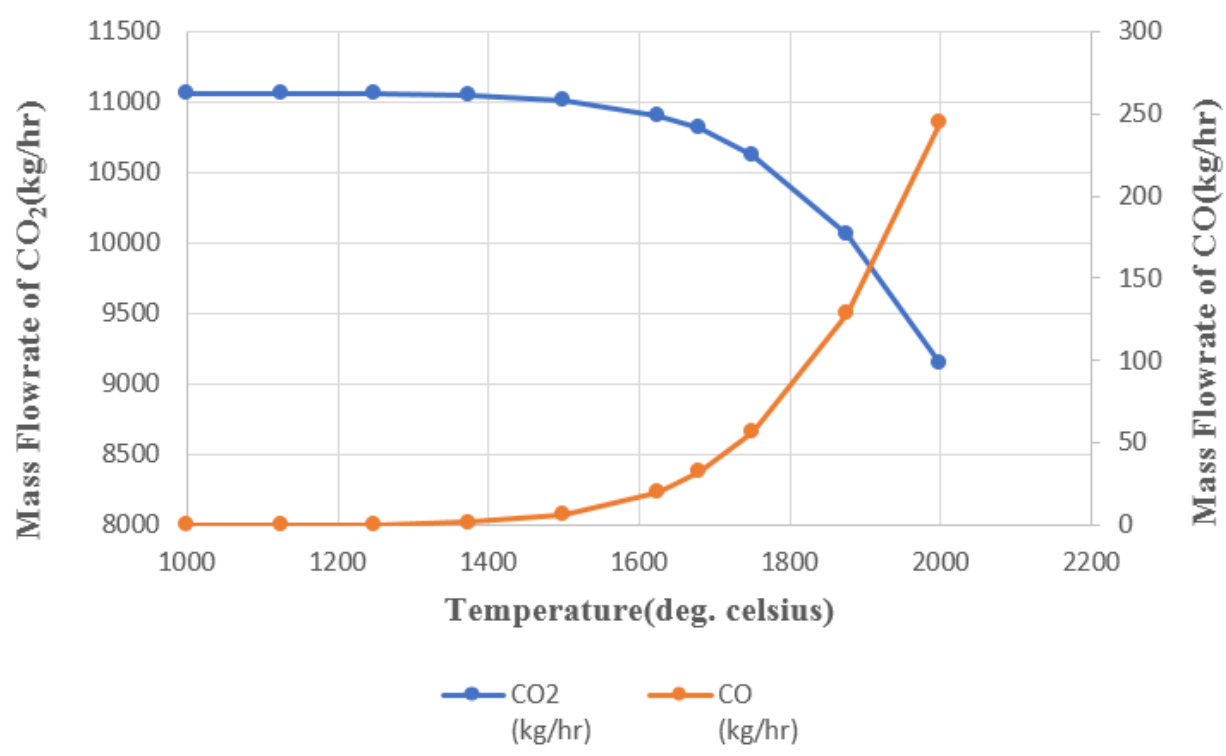

Figure-3. Effect of temperature on $\mathrm{CO}$ and $\mathrm{CO}_{2}$ Formation.

\section{Effect of Temperature on $\mathrm{NO}$ and $\mathrm{N}_{2}$ Formation}

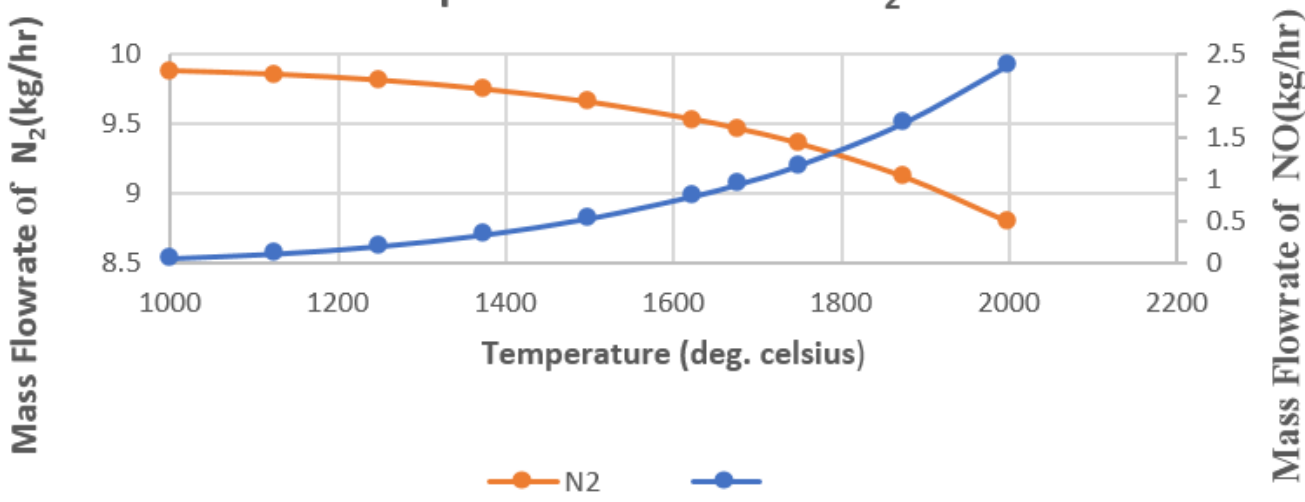

Figure-4. Effect of Temperature on $\mathrm{NO}$ and $\mathrm{N}_{2}$ Formation.
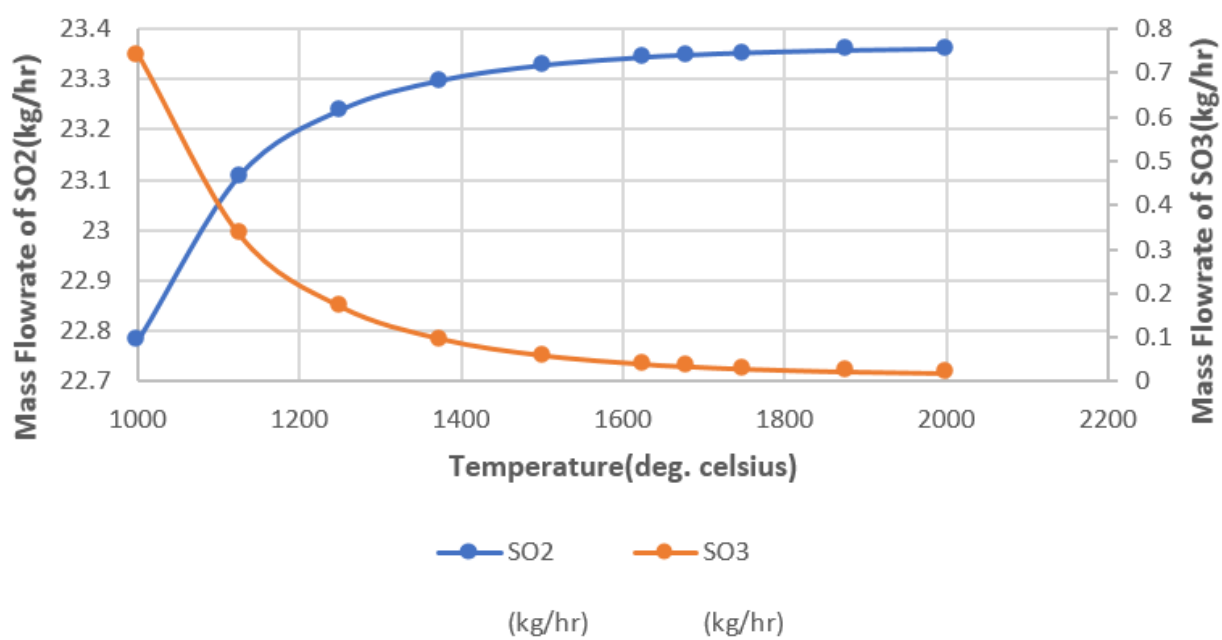

Figure-5. Effect of Temperature on $\mathrm{SO}_{2}$ and $\mathrm{SO}_{3}$ Formation. 


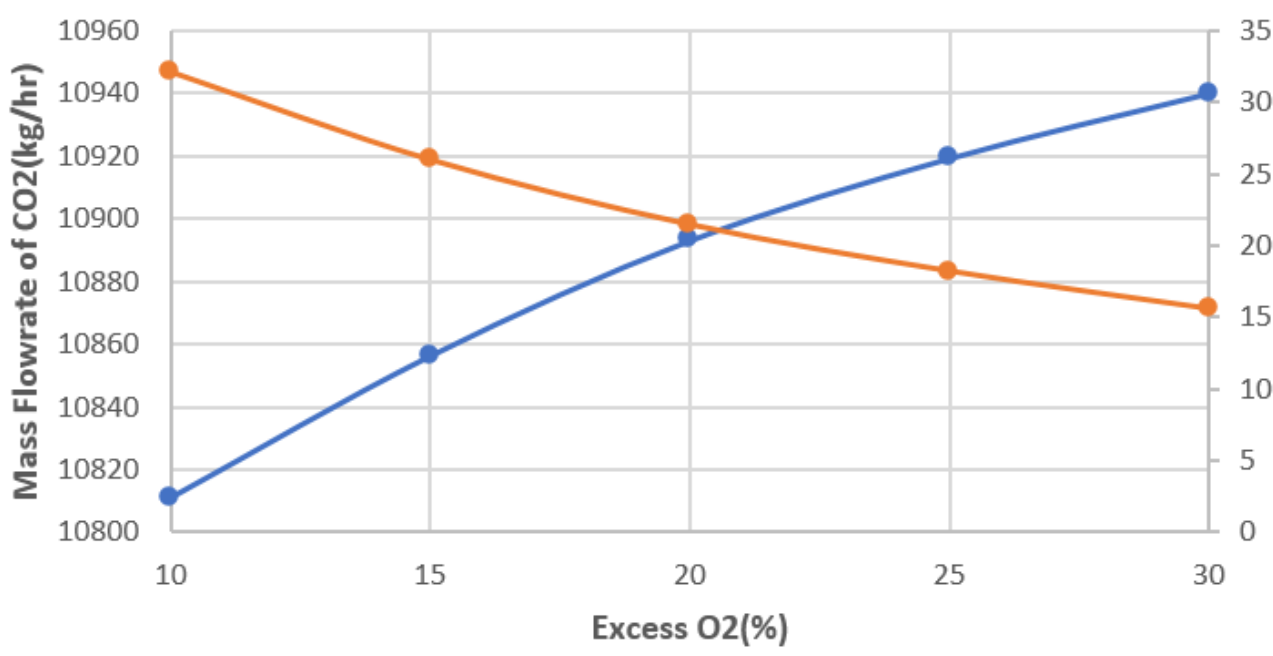

Figure-6. Effect of Excess $\mathrm{O}_{2}(\%)$ on $\mathrm{CO}_{2}$ and $\mathrm{CO}$ Formation.

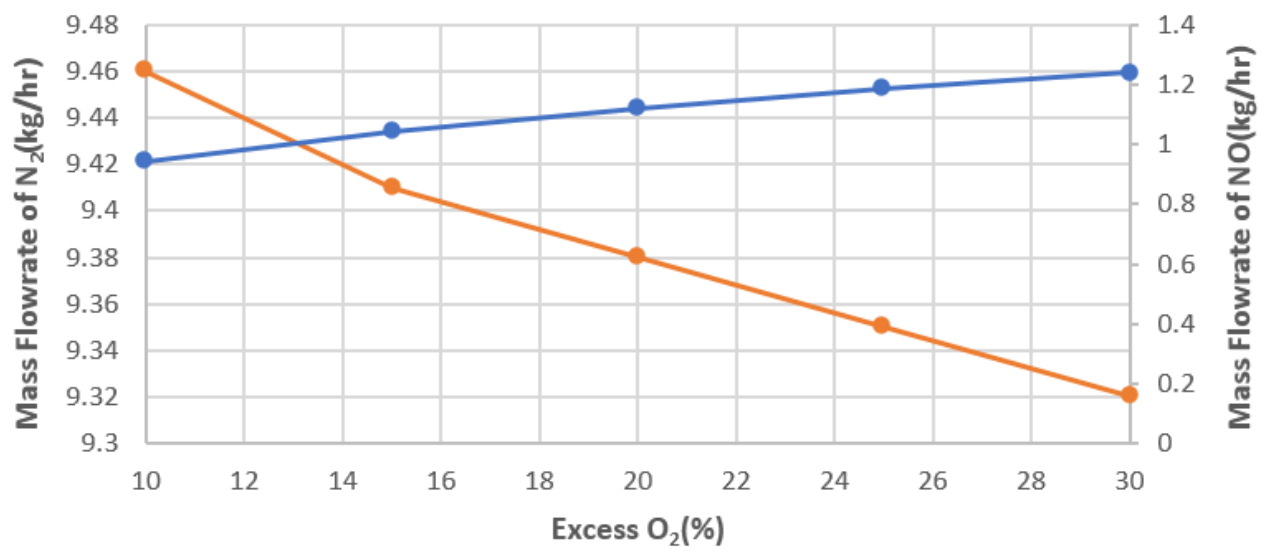

$\longrightarrow \mathrm{N} 2 \longrightarrow \mathrm{NO}$

Figure-7. Effect of Excess $\mathrm{O}_{2}(\%)$ on $\mathrm{N}_{2}$ and NO Formation.

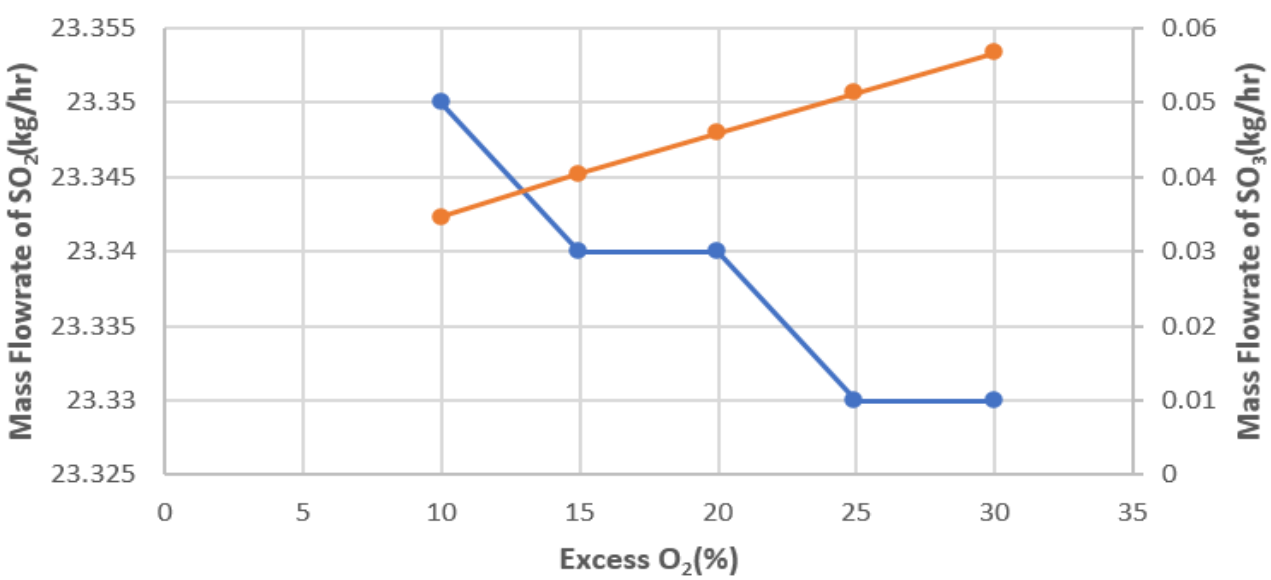

$-\mathrm{SO}_{2} \longrightarrow \mathrm{SO} 3$

Figure-8. Effect of Excess $\mathrm{O}_{2}$ on $\mathrm{SO}_{2}$ and $\mathrm{SO}_{3}$ Formation.

The thermal efficiency of a boiler can be calculated by the direct method (input-output method) or otherwise known as fuel-to-steam efficiency and it is given by: 
Boiler Efficiency $=\frac{\text { Heat Output }}{\text { Heat Input }} * 100 \%$

Boiler Efficiency $=\frac{Q *(H 2-H 1)}{q * G C V} 100 \%$

$\mathrm{Q}=$ Quantity of Steam generated $=6679 \mathrm{~kg} / \mathrm{h}$

$\mathrm{H}_{2}=$ Enthalpy of steam at boiler output.

From steam tables, at $124.61 \mathrm{bar}$ and $537.78^{\circ} \mathrm{C}, \mathrm{H}_{2}=3442.96 \mathrm{~kJ} / \mathrm{kg}$

$\mathrm{H}_{1}=$ Enthalpy of feed water

From steam tables, at $1.01235 \mathrm{bar}$ and $25^{\circ} \mathrm{C}, \mathrm{H}_{1}=104.8 \mathrm{~kJ} / \mathrm{kg}$

$\mathrm{q}=$ Fuel Quantity $=100 \mathrm{~kg} / \mathrm{h}$

$\mathrm{GCV}=$ Gross Calorific Value

GCV can be estimated using Dulong's formula:

$$
\mathrm{GCV}=\left[\frac{1}{100}\left(8080 \mathrm{C}+34500\left(H-\frac{o}{8}\right)+2240 S\right] \mathrm{kCal} / \mathrm{kg}\right.
$$

From the Proximate Analysis(\%) in Table 1,

$\mathrm{C}=67.1 \%, \mathrm{H}=4.8 \%, \mathrm{~S}=1.3 \%, \mathrm{O}=16.4 \%$

$$
\begin{aligned}
& \mathrm{GCV}=\left[\frac{1}{100}\left(8080(67.1)+34500\left(4.8-\frac{16.4}{8}\right)+2240(1.3)\right] \mathrm{kCal} / \mathrm{kg}\right. \\
& =\left[\frac{1}{100}(8080(67.1)+34500(2.75)+2240(1.3)] \mathrm{kCal} / \mathrm{kg}\right. \\
& =\frac{1}{100}[542168+94875+2912] \\
& \text { GCV }=\frac{639955}{100}=6399.55 \mathrm{kCal} / \mathrm{kg} \\
& \text { GCV }=6399.55 * 4.184=26750.119 \mathrm{~kJ} / \mathrm{kg} \\
& \text { Boiler Efficiency }=\frac{6697 *(3442.96-104.8)}{1000 * 26750.119} * 100 \% \\
& =\frac{6697 * 3338.16}{26750119} * 100 \% \\
& 26750119 * 100 \%=83.6 \%
\end{aligned}
$$

Thus, the thermal efficiency for the process was determined to be approximately $84 \%$. 


\section{CONCLUDING REMARKS}

The usage of fossil fuel, most especially coal for energy generation comes with its attendant mitigation and litigation due to the emission of pollutant gases that has adverse effects on the environment. Several clean coal technologies has been proposed by researchers over the years, of which oxy-fuel coal combustion is one. Oxy-fuel Combustion is a technology with the potential of drastically reducing the amount of $\mathrm{CO}_{2}$ emission, it relies on the use of oxygen and recycled $\mathrm{CO}_{2}$ instead of air as the oxidant. This helps to reduce the amount of the $\mathrm{CO}_{2}$ and $\mathrm{NOx}$ emissions. Hence, in this study, the design focused on the components of flue gas produced and their amounts for oxy-fuel combustion in a coal-fired power plant (CFPP) using Aspen plus 11. The boiler efficiency using the direct (input-output) method was also applied and calculated.

The amount of each component in flue gas in coal-fired processes with air or $\mathrm{O}_{2} / \mathrm{CO}_{2}$ (using recycle of $20 \%$, $40 \%, 60 \%$ and $80 \%$ of $\mathrm{CO}_{2}$ ) as oxidizer was obtained. From the process simulation, as the recycle $\%$ of $\mathrm{CO}_{2}$ was increased, the flame temperature, $\mathrm{CO}$ and $\mathrm{NOx}$ emissions were reduced. The simulation results of air combustion were compared with that of oxy-fuel combustion with $80 \%$ recycle. The comparison indicated a drop in the flame temperature from $1894^{\circ} \mathrm{C}$ when air was used as oxidizer to $1679^{\circ} \mathrm{C}$ for oxy-fuel combustion with $80 \%$ recycle. There was also a reduction in the amount of NOx produced. However, the SOx levels were constant for both combustion processes. The Gross Calorific Value (GCV) of the coal was calculated from its proximate analysis using Dulong's formula and it was used to estimate the Boiler Efficiency using the Direct (Input-Output) method and a value of 83.6\% was obtained. Although, oxy-fuel combustion technique has been investigated in the past by other investigators, the approach used in this study and the selectivity analysis using different operating parameters and conditions to get a boiler efficiency of $84 \%$ is novel to the best of knowledge of the authors. The technique implored in this study may be explored by energy key players in the combustion of coal for energy derivation.

Funding: This study received no specific financial support.

Competing Interests: The authors declare that they have no competing interests.

Acknowledgement: All authors contributed equally to the conception and design of the study.

\section{REFERENCES}

[1] A. Sharma and A. C. Tiwari, "Design of the horizontal fire tube boiler for the commercial cooking of Indian food," Journal of Mechanical Engineering and Technology, vol. 5, pp. 1-13, 2017.

[Q] IEA, CO2 emissions for fuel combustion-highlights: International Energy Agency, 2011.

[3] IPCC Intergovernmental Panel on Climate Change, "Retrieved from http://www.ipcc.ch," 2007.

[4] T. Wall, Y. Liu, C. Spero, L. Elliott, S. Khare, R. Rathnam, and C. Sheng, "An overview on oxyfuel coal combustionState of the art research and technology development," Chemical Engineering Research and Design, vol. 87, pp. 1003-1016, 2009.Available at: https://doi.org/10.1016/j.cherd.2009.02.005.

[5] Y. Cao, P. Lin, Y. Luo, N. Chen, K. Xiao, and F. Chen, "Research progress of oxy-fuel combustion for coal-fired utility boilers," Boiler Technology, vol. 1, pp. 45-48, 2012.

[6] B. J. Buhre, L. K. Elliott, C. Sheng, R. P. Gupta, and T. F. Wall, "Oxy-fuel combustion technology for coal-fired power generation," Progress in Energy and Combustion Science, vol. 31, pp. 283-307, 2005.Available at: https://doi.org/10.1016/j.pecs.2005.07.001.

[7] M. Habib, H. Badr, S. Ahmed, R. Ben-Mansour, K. Mezghani, S. Imashuku, and A. Mitsos, "A review of recent developments in carbon capture utilizing oxy-fuel combustion in conventional and ion transport membrane systems," International Journal of Energy Research, vol. 35, pp. 741-764, 2011 .Available at: https://doi.org/10.1002/er.1798.

[8] I. Suarez-Ruiz, M.A. Diez, and F. Rubiera, "Coal: In New Trends in Coal Conversion," ed Amsterdam, The Netherlands: Elsevier, 2019, pp. 1-30. 
[9] A. Wienese, "Boilers, boiler fuel and boiler efficiency," Proceeding of South African Sugar Technology Association, vol. 75, pp. 275-281, 2001.

[10] Anon, "BS 845 methods for assessing thermal performance of boilers for steam, hot water and high temperature heat transfer fluids," ed: British Standards Institution, 1987, p. 18.

[11] H. Sun, T. Zhao, and G. Cai, "The application and development of process simulation," Computer and Applied Chemistry, vol. 24, pp. 1285-1288, 2007.

[12] D. Sun, Analysis and optimization to the new near zero emission coal utilization technology with combined gasification and combustion. Hangzhou: Zhejiang University, 2007.

[13] B. Liu, X. Yang, W. Song, and W. Lin, "Process simulation development of coal combustion in a circulating fluidized bed combustor based on Aspen Plus," Energy \& Fuels, vol. 25, pp. 1721-1730, 2011.Available at: https://doi.org/10.1021/ef101439s.

[14] A. O. Odeh and N. A. Okafor, "Steady state simulation of coal gasification in a fluidized Bed Gasifier," Nigerian Research Journal of Engineering and Environmental Sciences, vol. 3, pp. 655-664, 2018.

[15] L. Zhou, Z. Zhang, C. Chivetta, and R. Agarwal, "Process simulation and validation of chemical-looping with oxygen uncoupling (CLOU) process using Cu-based oxygen carrier," Energy \&̊ Fuels, vol. 27, pp. 6906-6912, 2013.Available at: https://doi.org/10.1021/ef401637q.

[16] A. Geete and A. Khandwawala, "Thermodynamic analysis of 120MW thermal power plant with combined effect of constant inlet pressure (124.61bar) and different inlet temperatures," Case Studies in Thermal Engineering, vol. 1, pp. 1725, 2013.Available at: https://doi.org/10.1016/j.csite.2013.08.001.

[17] A. O. Odeh, "Exploring the potential of petrographics in understanding coal pyrolysis," Energy, vol. 87, pp. 555-565, 2015a.Available at: https://doi.org/10.1016/j.energy.2015.05.019.

[18] A. O. Odeh, "Oualitative and quantitative ATR-FTIR analysis and its application to coal char of different ranks," Journal of Fuel Chemistry and Technology, vol. 43, pp. 129-137, 2015b.Available at: https://doi.org/10.1016/s1872$5813(15) 30001-3$.

Views and opinions expressed in this article are the views and opinions of the author(s), International Journal of Natural Sciences Research shall not be responsible or answerable for any loss, damage or liability etc. caused in relation to/arising out of the use of the content. 